\title{
Review of Satellite Remote Sensing Use in Forest Health Studies
}

\author{
Junming Wang ${ }^{*}, 1$, Theodore W. Sammis ${ }^{2}$, Vincent P. Gutschick ${ }^{3}$, Mekonnen Gebremichael ${ }^{4}$, \\ Sam O. Dennis ${ }^{1}$ and Robert E. Harrison ${ }^{1}$
}

\author{
${ }^{I}$ Department of Agricultural Sciences, Tennessee State University, Nashville, TN 37209, USA \\ ${ }^{2}$ Department of Plant and Environmental Sciences, New Mexico State University, P.O. Box 30003, MSC 3Q, \\ Las Cruces, 88003-8003, New Mexico \\ ${ }^{3}$ Biology Department, New Mexico State University, P.O. Box 30001, MSC 3AF, Las Cruces, 88003-8001, New Mexico \\ ${ }^{4}$ Department of Civil and Environmental Engineering, University of Connecticut Storrs, CT 06269-2037, USA
}

\begin{abstract}
Satellite remote sensing has been used in forest health management as a method for vegetation mapping, fire fuel mapping, fire risk estimation, fire detection, post-fire severity mapping, insect infestation mapping, and relative water stress monitoring. This paper reviews the use of satellite remote sensing in forest health studies, including current research activities; the satellite sensors, methods, and parameters used; and their accuracy.

The review concludes that the Moderate Resolution Imaging Spectroradiometer satellite data (MODIS) are more appropriate for most of the remote sensing applications for forest health than other current satellite data when considering temporal and spatial resolutions, cost, and bands. MODIS has a 1-2 day temporal and a 250-1000 m spatial resolution; the data are free and cover more spectral bands than other satellites (up to 36 bands). We recommend that physical and physiological modeling (e.g., evapotranspiration and biomass growth) be developed for remote sensing of forest health. Some additional satellite sensors, such as for high temperature estimates (as high as $1800 \mathrm{~K}$ ) and sensors of narrow bands, are also needed.
\end{abstract}

Keywords: Forest health, remote sensing, MODIS, satellite.

\section{INTRODUCTION}

Campbell [1] defines remote sensing as "the practice of deriving information about the earth's land and water surfaces using images acquired from an overhead perspective, using electromagnetic radiation in one or more regions of the electromagnetic spectrum, reflected or emitted from the earth's surface." Remote sensors can be deployed on satellites, airplanes, balloons, or remote-controlled vehicles.

Current and past satellite remote sensing of forest health has focused on the following categories: vegetation and landscape classification, biomass mapping, invasive plant detection, fire fuel mapping, canopy or foliar water stress, fire detection and progression mapping, post-fire burn area and severity mapping, and insect infestation detection. Most of these studies have analyzed spectral signatures or simple indices (calculated from reflectance data) such as the Normalized Difference Vegetation Index (NDVI). Little has been done for remote sensing of absolute forest water stress (e.g., evapotranspiration [ET]) and biomass growth using physically- and physiologically-based algorithms. Previous studies estimated biomass by using NDVI or other simple indices using correlation and regression methods. These studies may not result in accurate biomass growth estimates for other locations and different environmental conditions [2].

*Address correspondence to this author at the Department of Agricultural Sciences, Tennessee State University, Nashville, TN 37209, USA; Tel: 615963-1827; Fax: 615-963-5183; E-mail: wangjunming@hotmail.com
Institutes working on satellite remote sensing of forest health include the United States Forest Service (USFS), universities, state forest services, federal institutes, and private companies. Most of the studies (41\%) have been conducted by the USFS, but universities represent $28 \%$ of the research in forest remote sensing (based on submitted papers in Beck and Gessler [3]).

\section{SATELLITE SENSORS USED IN REMOTE SENSING OF FOREST HEALTH}

An understanding of satellite sensors is necessary in order to understand the remote sensing capabilities of each satellite, as well as the types of tools that can be developed to make forest management decisions using the satellite information. There are nine satellite sensors that are widely used in forest health research (Tables $\mathbf{1}$ and 2). The major satellite sensors are Advanced Spaceborn Thermal Emission and Reflection Radiometer (ASTER), Advanced Land Imager (ALI), Advanced Very High Resolution Radiometer (AVHRR), MODIS, Landsat 5 TM (Thematic Mapper), Landsat 7 ETM+ (Enhanced Thematic Mapper Plus), Spot 4 and 5, Quickbird-2, and IKONOS-2. Each sensor has its own advantages and disadvantages in spatial and temporal resolutions, cost, and acquisition time. The high spatial resolution sensors (15-120 m), such as ASTER, ALI, and the Landsats, cannot give a high temporal resolution; their temporal resolution is more than 16 days. Additionally, the cost of data from these sensors ranges from $\$ 80$ to $\$ 600$ per scene (each scene can cover $25-60 \mathrm{~km}^{2}$ ) (Landsat data is free currently). 
Quickbird-2, IKONOS-2, and Spot 4 and 5 have high spatial $(0.61-20 \mathrm{~m})$ and temporal (1-3.5 days) resolutions. However, the temporal resolution is for future or requested data. Past data for an area may not be available for the 1-3.5 day resolution, because if data are not requested, they will not be collected. In addition, the cost to sense an area on the scale of a forest will be large ( $\$ 15$ to $\$ 22.50$ per $\mathrm{km}^{2}$ for Quickbird-2 and IKONOS-2, and $\$ 3375$ to $\$ 6750$ for each Spot 5 scene of $56 \mathrm{~km}^{2}$ ). Moreover, the satellites do not have thermal bands and, consequently, cannot provide data to map ET using an energy balance method (e.g., [4-6]). MODIS data have a one- or two-day frequency and a $250-1000 \mathrm{~m}$ spatial resolution, both of which are adequate for forest health monitoring. Also, the data are free and cover more bands than other satellites ( 36 bands total).

The data for all sensors are available as both raw data and processed data, where the raw data is corrected for atmospheric effects and algorithms are used to produce specified products such as surface temperature.

The Landsat 7 ETM+ data have the highest thermal band resolution among all current satellite sensors. The Landsat 5 $\mathrm{TM}$ and $7 \mathrm{ETM}+$ sensors have high resolutions in the visible and near and short wave infrared bands. However, because of hardware limitations, historical data may not be available for a location. The temporal resolution of 16 days or more can make Landsat imagery acquisition problematic. For example, it cannot be used in emergency situations such as fires. The extended temporal resolution is even a problem for forest water stress monitoring. Finally, the scene size is not appropriate for national mapping.

Satellite instrument problems that degrade sensing products can occur. Due to problems with the scan line corrector on the Landsat 7 ETM+ sensor, only the middle 20 $\mathrm{km}$ of the imagery is currently useful [7].

Landsat does not provide higher-level products such as surface temperature and reflectance, which are important variables for water stress (ET) models based on energy balance $[4,8]$. With Landsat, water stress must be calculated from lower-level data.

In addition to Landsats 5 and 7, Landsat also launched Landsats 1 through 4 in different years $(1972,1975,1978$, and 1982, respectively). Landsat 4 had the same bands as Landsat 5. Landsat data now are free at USGS Earth Resources Observation and Science (EROS) Center.

The ASTER sensor was launched the same year as the Landsat 7 ETM+ satellite (Table 1), but the instrumentation package was changed to record more bandwidths (Table 2 ). ASTER also includes a telescope that is used to view backward in the near infrared spectral band (band 3B) for stereoscopic capability. The ASTER data have similar applications as Landsat because they have similar bands and resolutions. All ASTER data were free before March 2006; now each scene of both lower- and higher-level products is about $\$ 80$. Except for Landsat 7 ETM+, ASTER data have the highest thermal band resolution among all current satellite sensors, and they have high resolution in the visible and near infrared bands.

ASTER higher-level products provide the temperature and reflectance data needed as inputs for the energy balance- based ET model $[8,9]$. Like Landsat, the temporal resolution of 16 days or more makes ASTER data application in forest health sometimes problematic. Consequently, ASTER data are more appropriate for research purposes than operational applications.

The Spot 4 satellite sensor was launched one year before Landsat 7 ETM+ and one and a half years before ASTER sensor; Spot 5 was launched about 4 years after Spot 4 (Table 1). The instrumentation packages of Spot 4 and 5 were different from ASTER and Landsat (Table 2); additionally, these satellites are owned by a private company (Space Imaging) in France and not by NASA. The spectral resolution and bandwidth of Spot 4 and 5 are limiting compared to Landstat and ASTER (Table 2), but the resolution is much higher. For example, Spot 5 has a $2.5 \mathrm{~m}$ spatial resolution for the panchromatic band and a 3 day temporal resolution, compared to $15 \mathrm{~m}$ and 16 days for both Landstat and ASTER. Spot data have been used for monitoring forest fire progression, post-fire severity mapping, invasive weed detection, and vegetation mapping [7]. The biggest drawback of using Spot imagery is the high cost of the delivered data. Use of Spot 4 costs $\$ 1200-\$ 1900$ per scene, plus additional fees for rush programming and delivery if the need is urgent (as in the case of fires). The USFS Remote Sensing Applications Center (RSAC) typically pays about $\$ 9175$ for a Spot 4 scene for Burned Area Emergency Response (BAER) support. A Spot 5 scene costs $\$ 3300$, plus additional fees for rush programming and delivery. RSAC typically pays about $\$ 10575$ for a Spot 5 scene for BAER support [7]. To ensure prompt image delivery for emergency events, researchers can order Spot imagery without any terrain correction. This adds a few hours of processing time to make the imagery usable for immediate post-fire assessment, but saves days of processing time [7]. Spot does not have thermal infrared bands and cannot provide surface temperature products for ground heat mapping or the calculation of ET based on energy balance.

Several AVHRR sensors have been launched since June 11, 1978, and have provided data continuously. The temporal resolution is daily with a spectral resolution of 4 to 5 bands; the spatial resolution is $1100 \mathrm{~m}$. These sensors are owned by the National Oceanic and Atmospheric Administration (NOAA). These sensors have fewer spectral bands than Landsat 5 and 7 , ASTER, ALI, and MODIS. AVHRR's objective is to provide radiance data for the investigation of clouds, land-water boundaries, snow and ice extent, ice or snow melt inception, day and night cloud distribution, temperatures of radiating surfaces, and sea surface temperature.

Other applications include agricultural assessment, land cover mapping, fire and burnt area mapping, production of large-area maps, and evaluation of regional and continental snow cover. The AVHRR raw data (not geo-registered) are free. However, dates are provided only in limited sets. The geo-registered raw data are $\$ 190$ per scene. The AVHRR data include thermal infrared data but not derived temperature data that can be used to estimate energy balancebased ET $[8,9]$. The disadvantage to using AVHRR imagery is the coarse spatial resolution, which often is too coarse for fire analysis [7]. 
Table 1. Launch Date, Status, and Spatial and Temporal Resolutions of Selected Satellite Sensors

\begin{tabular}{|c|c|c|c|c|c|c|}
\hline & Landsat 5 TM/7 ЕTM+ & ASTER & Spot $4^{\text {(a) }}$ & Spot $5^{\text {(a) }}$ & AVHRR & IKONOS-2 \\
\hline Owner & NASA & NASA & $\begin{array}{l}\text { Space Imaging } \\
\text { (France) }\end{array}$ & $\begin{array}{l}\text { Space Imaging } \\
\text { (France) }\end{array}$ & NOAA & $\begin{array}{l}\text { Space } \\
\text { Imaging } \\
\text { (France) }\end{array}$ \\
\hline Launch Date & March 1984/April 1999 & December 1999 & March 1998 & May 2002 & $\begin{array}{l}\text { Since June 11, 1978, } \\
\text { several satellite sensors } \\
\text { have been launched }\end{array}$ & $\begin{array}{c}\text { September } \\
1999\end{array}$ \\
\hline Status & $\begin{array}{l}\text { Landsat } 7 \text { ETM+: the Scan Line } \\
\text { Corrector aboard malfunctioned on } \\
\text { May } 31,2003 \text {. Data only in the } \\
\text { middle part of the images can be used. }\end{array}$ & Working & Working & Working & $\begin{array}{l}\text { Recently launched } \\
\text { sensors (2000, 2002, } \\
\text { 2005) still work well. } \\
\text { Continuous historical } \\
\text { data from } 1978 \text { to } \\
\text { present are available. }\end{array}$ & Working \\
\hline $\begin{array}{c}\text { Spatial } \\
\text { Resolution (m) }\end{array}$ & $15-120$ & $15-90$ & $\begin{array}{c}20(10 \mathrm{~m} \\
\text { monochromatic) }\end{array}$ & $\begin{array}{c}10(2.5 \mathrm{~m} \\
\text { panchromatic })\end{array}$ & 1100 & $1-4$ \\
\hline $\begin{array}{c}\text { Temporal } \\
\text { Resolution (day) }\end{array}$ & $16^{(\mathrm{b})}$ & $16^{(\mathrm{b})}$ & $3^{(\mathrm{b})}$ & $3^{\text {(b) }}$ & 1 & $1-3^{(b)}$ \\
\hline $\begin{array}{l}\text { Scene Size } \\
(\mathbf{k m} \times \mathbf{~ k m )}\end{array}$ & $185 \times 185$ & $60 \times 60$ & $56 \times 56$ & $56 \times 56$ & $2400 \times 6400$ & $11.3 \times 11.3$ \\
\hline $\begin{array}{c}\text { Price for each } \\
\text { achieved raw } \\
\text { data scene (US \$) }\end{array}$ & 600 & Free $^{(c)}$ & $1200-1900$ & $3375-6750$ & $\begin{array}{l}\text { Free for raw L1B data; } \\
\$ 190 \text { for geo registered } \\
\text { L1B. }\end{array}$ & $\begin{array}{l}7 / \mathrm{km}^{2} \\
\text { minimum } \\
49 \mathrm{~km}^{2}\end{array}$ \\
\hline
\end{tabular}

\begin{tabular}{|c|c|c|c|}
\hline & MODIS & ALI & Quickbird-2 \\
\hline Owner & NASA & NASA & DigitalGlobe (USA) \\
\hline Launch Date & $\begin{array}{l}\text { Decmber 1999, Terra satellite; } \\
\text { April 2002, Aqua satellite. }\end{array}$ & November 2000 & October 2001 \\
\hline Status & $\begin{array}{c}\text { Terra MODIS band } 5 \text { and Aqua MODIS } \\
\text { band } 6 \text { have erroneous data. }\end{array}$ & Working & Working \\
\hline Spatial Resolution (m) & $250-1000$ & 30 (10 m panchromatic) & $0.6-2.44$ \\
\hline Temporal Resolution (day) & $1-2$ & $16^{(\mathrm{b})}$ & $1-3.5^{(\mathrm{b})}$ \\
\hline Scene Size $(\mathbf{k m} \times \mathbf{k m})$ & $2300 \times 2300$ & $37 \times 185$ & $16.5 \times 16.5$ \\
\hline $\begin{array}{l}\text { Price for each achieved } \\
\text { raw data scene (US \$) }\end{array}$ & Free $^{(c)}$ & $250-500$ & $22.5 / \mathrm{km}^{2}$, minimum $25 \mathrm{~km}^{2}$ \\
\hline
\end{tabular}

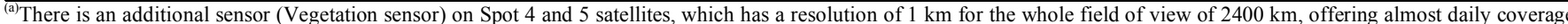
of the whole of the earth's surface. Of its 4 spectral bands, 3 bands characterize vegetation $(0.61-0.68 \mu \mathrm{m}$ red band, $0.78-0.89 \mu \mathrm{m}$ near infrared, and 1.58 - $1.75 \mu \mathrm{m}$ short wave infrared) and the fourth band $(0.43-0.47 \mu \mathrm{m}$, blue) is for atmospheric correction.

${ }^{(b)}$ This is the potential temporal resolution for a location because the historical data may have not been available if no one requested that the satellite collect data on a certain date and at a certain location.

${ }^{(c)}$ The price of higher-level products (such as temperature and reflectance) derived from the raw radiance data are $\$ 80$ per scene. Only ASTER and MODIS provide higher-level products.

There are two MODIS sensors, one on Terra satellite, which also carries the ASTER sensor and the other on Aqua satellite. Although Terra ASTER and MODIS are on the same satellite, the temporal resolution of this MODIS is much shorter than ASTER's (1 day versus 16 days) because the MODIS view field is much larger than ASTER's (2300 $\mathrm{km}^{2}$ versus $60 \mathrm{~km}^{2}$ ). Terra MODIS and ASTER were launched by NASA in the same year as Landsat 7 ETM+ (Table 1), but the MODIS spatial resolution was coarse. The MODIS sensors' temporal resolution is daily with a spectral resolution of 36 bands (Tables 1 and 2). Currently, MODIS data are free. MODIS data have been used in monitoring forest fire, post-fire burn area mapping, vegetation classification, biomass estimation, and soil degradation.
Because the first seven bands of MODIS were designed to simulate the Landsat sensors-except for the spatial resolution-users can view MODIS imagery in much the same way as Landsat imagery [7]. MODIS also provides products of surface temperature and reflectance, which drive energy balance-based ET modeling [8, 9]. Like AVHRR data, the disadvantage to using MODIS imagery is the coarse spatial resolution. The finest pixel size is $250 \mathrm{~m}$, which often is too coarse for fire analysis [7].

NASA launched the Advanced Land Imager (ALI) in November 2000 (Table 1) to supplement data from Landsat. Because ALI follows the same orbit track as Landsat 7, images can be acquired from this satellite in addition to Landsat 7 to achieve better temporal resolution. 
Table 2. Spectral and Spatial Resolutions and Principle Application for Landsat 5 TM, Landsat 7 ETM+, ASTER, ALI, Quickbird-2, IKONOS-2, Spot and MODIS Satellite Sensors

\begin{tabular}{|c|c|c|c|c|c|c|c|c|c|c|}
\hline \multirow[b]{2}{*}{ Spectral Resolution $(\mu \mathrm{m})$} & \multirow[b]{2}{*}{$\begin{array}{l}\text { Spectral } \\
\text { Location }^{(\text {a) }}\end{array}$} & \multicolumn{8}{|c|}{ Spatial Resolution (m) } & \multirow[b]{2}{*}{ Principle Application $^{(b)}$} \\
\hline & & 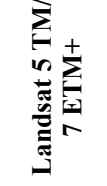 & 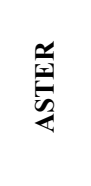 & $\bar{z}$ & 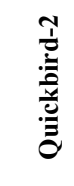 & $\begin{array}{l}\tilde{y} \\
0 \\
0 \\
z \\
0 \\
y\end{array}$ & $\begin{array}{l}\frac{n}{+} \\
\frac{0}{0} \\
\frac{2}{n}\end{array}$ & 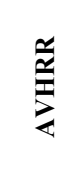 & $\frac{\mathscr{a}}{\hat{0}}$ & \\
\hline $\begin{array}{l}\text { All: 0.52-0.60, except ALI: } 0.525- \\
0.605 ; \text { Spot: } 0.50-0.59 \\
\text { MODIS:0.545- } 0.560\end{array}$ & G & $30 / 30$ & 15 & 30 & 2.44 & 4 & $20 / 10$ & N/A & 500 & $\begin{array}{l}\text { Green reflectance by } \\
\text { healthy vegetation }\end{array}$ \\
\hline $\begin{array}{l}\text { All: } 0.63-0.69 \text {, except } \\
\text { Spot: } 0.61-0.68 \text {; AVHRR: 0.58- } \\
0.68\end{array}$ & $\mathrm{R}$ & $30 / 30$ & 15 & 30 & 2.44 & 4 & $20 / 10$ & 1100 & 250 & $\begin{array}{l}\text { Chlorophyll absorption for } \\
\text { plant species differentiation, } \\
\text { forest vigor }\end{array}$ \\
\hline 1.23-1.25 MODIS only & SWIR & N/A & N/A & N/A & $\mathrm{N} / \mathrm{A}$ & N/A & $\mathrm{N} / \mathrm{A}$ & N/A & 500 & $\begin{array}{l}\text { Leaf area index, land and } \\
\text { vegetation classification }\end{array}$ \\
\hline $\begin{array}{l}\text { All: } 1.55-1.75 \text {, except ASTER: } \\
\text { 1.6-1.7; } \\
\text { Spot: } 1.58-1.75 \text {; MODIS: } 1.628- \\
\text { 1.652; AVHRR:1.58-1.64, } \\
\text { Daytime only, available for } \\
\text { AVHRR 14-16 (After 1998-05-13) }\end{array}$ & SWIR & $30 / 30$ & 30 & 30 & N/A & $\mathrm{N} / \mathrm{A}$ & $20 / 20$ & 1100 & 500 & $\begin{array}{l}\text { Vegetation moisture } \\
\text { measurement, snow cloud } \\
\text { differentiation }\end{array}$ \\
\hline $\begin{array}{l}\text { All: 0.52-0.90, except ASTER: } \\
0.52-0.60 ; \\
\text { Quickbird-2: } 0.45-0.90 ; \\
\text { IKONOS-2: } 0.526-0.929 \\
\text { Spot 4: } 0.61-0.68 \\
\text { Spot 5: } 0.48-0.71\end{array}$ & $\begin{array}{l}\text { All: Panchromatic, } \\
\text { G-NIR, } \\
\text { except ASTER: G; } \\
\text { Quickbird-2: B- } \\
\text { NIR; Spot 4: R }\end{array}$ & $\mathrm{N} / \mathrm{A} / 15$ & 15 & 10 & 0.61 & 1 & $10 / 2.5$ & 1100 & $\mathrm{~N} / \mathrm{A}$ & Vegetation mapping \\
\hline
\end{tabular}

\section{Web sites:}

Landsat: http://landsat7.usgs.gov (user name and password required), ASTER: http://lpdaac.usgs.gov/aster/asterdataprod.asp, ALI: http://eo1.gsfc.nasa.gov/Technology/ ALIhome1.htm, Quickbird-2: http://www.digitalglobe.com/, IKONOS-2: http://www.geoeye.com/CorpSite/products/Default.aspx, Spot: www.spot.com, AVHRR: http://edc.usgs. gov/products/satellite/avhrr.html\#description, MODIS: http://modis.gsfc.nasa.gov, ${ }^{(a)}$ B: blue, G: green, R: red, NIR: near infrared, SWIR: short wave infrared.

(b) The principle applications were concluded by Nicholas M. Short, Sr. (http://rst.gsfc.nasa.gov/Intro/Part2 Vं20.html).

(c) N/A: Not available.

(d) MODIS has an additional 29 bands from 0.405 to $14.385 \mu \mathrm{m}$, which include 16 thermal infrared bands from 3.66 to $14.385 \mu \mathrm{m}$.

The ALI is an experimental sensor, and provides Landsat-type panchromatic and multi-spectral bands. Consequently, the data applications are similar to those for Landsat. The bands have been designed to mimic six Landsat MSS bands, with three additional bands covering 0.433$0.453 \mu \mathrm{m}, 0.845-0.890 \mu \mathrm{m}$, and 1.20-1.30 $\mu \mathrm{m}$ (Table 2). In theory, this sensor could be a replacement for Landsat 7 [7]. Archived ALI radiometrically-corrected data are $\$ 250$ per scene; archived radiometrically- and geometrically-corrected data are $\$ 500$ per scene. A Data Acquisition Request (DAR) must be submitted in order to collect a requested image for a specific area of interest. There will be a $\$ 750$ service fee for tasking the sensor(s).

Because this sensor is still experimental, NASA does not acquire the full $185 \mathrm{~km}^{2}$ footprint. ALI images are much narrower than a typical Landsat footprint. For example, the image acquired of the Old/Grand Prix fires was only $37 \mathrm{~km}$ 
wide and $185 \mathrm{~km}$ long [7]. The ALI sensor does not have any thermal bands.

Quickbird-2, owned by one of three private satellite companies offering remote sensing information for profit, was launched by DigitalGlobe Corporate in the U.S. in 2001 (Tables 1 and 2). Quickbird-2 has the highest spatial resolution in panchromatic, visible, and near infrared bands among current satellite sensors; it also has a high temporal resolution. The data are used for vegetation classification, invasive weed detection, insect infestation mapping, landscape classification, and forest fire fuel mapping. The cost of use is $\$ 22.50$ for $1 \mathrm{~km}^{2}$ of archived data, with a minimum order of $25 \mathrm{~km}^{2}$. New DARs must request at least $64 \mathrm{~km}^{2}$. Because Quickbird-2 has no thermal bands, surface temperature data can be neither estimated nor provided. Scene size is relatively small and may not be large enough for forest mapping. Costs also limit its use for forest health monitoring.

IKONOS-2 was launched in 1999 by Space Imaging, a private French company. Like Quickbird-2, IKONOS-2 collects high spatial resolution data (Tables $\mathbf{1}$ and 2). The cost of use is $\$ 7$ for $1 \mathrm{~km}^{2}$ of archived data, with a minimum order of $49 \mathrm{~km}^{2}$. New DARs cost $\$ 15$ for $1 \mathrm{~km}^{2}$, with a minimum order of $100 \mathrm{~km}^{2}$. After Quickbird-2, IKONOS-2 has the next-highest spatial resolution in the panchromatic, visible, and near infrared bands among current satellite sensors (Table 2). Consequently, IKONOS-2 data are used for vegetation classification, landscape classification, and burn area mapping. Like Quickbird-2, it has no thermal bands that can be used for surface temperature estimation.

\section{DATA FORMATS AND SOFTWARE TOOLS TO VIEW DATA}

The most commonly used satellite data formats are Hierarchical Data Format (HDF) and Geographic Tagged Image File Format (GeoTIFF). Data from NASA usually have these formats (Table 3). Some early satellites from NASA, like AVHRR and Landsat, have other data formats: Fast, National Landsat Archive Production System (NLAPS) Data Format, and National Imagery Transmission Format (NITF). Spot satellites from Space Imaging have special formats: Centre d'Archivage et de Prétraitement (CAP) and Digital Image Map (DIMAP), which is the new Spot product data format introduced in mid-2002 for the launch of the new Spot 5 satellite.

All of these data formats need special reader software to view the data, and most of these software readers are proprietary (Table 3). ENVI software, produced by ITT Corporation, can read all the satellite data formats mentioned. The price for the Windows version of ENVI is about $\$ 1250$ for educational institutions and $\$ 5000$ for commercial institutions.

There are also some free software packages available (Table 3). For example, HDFview, produced by NASA, can read HDF files. The source codes are in JAVA and can be downloaded for free.

It is possible for researches and other users to program their own software to read satellite data, but this requires much effort. For example, we tried to program a MODIS (L1 B $1000 \mathrm{~m}$ ) raw data reader to read MODIS raw data, which have the HDF format. However, the data inside the files can also have different formats. Some of the files contain compressed data formats inside the files, while others may just contain the uncompressed data.

\section{INDICES AND DATA TRANSFORMATIONS USED IN REMOTE SENSING OF FOREST HEALTH}

An index is formed from combinations of several spectral values from satellite data that are added, divided, or multiplied in a manner designed to yield a single value [1]. In satellite remote sensing for forest health, the indices of vegetation, burn,

Table 3. Selected Satellite Data Formats and Software Tools to Read the Data

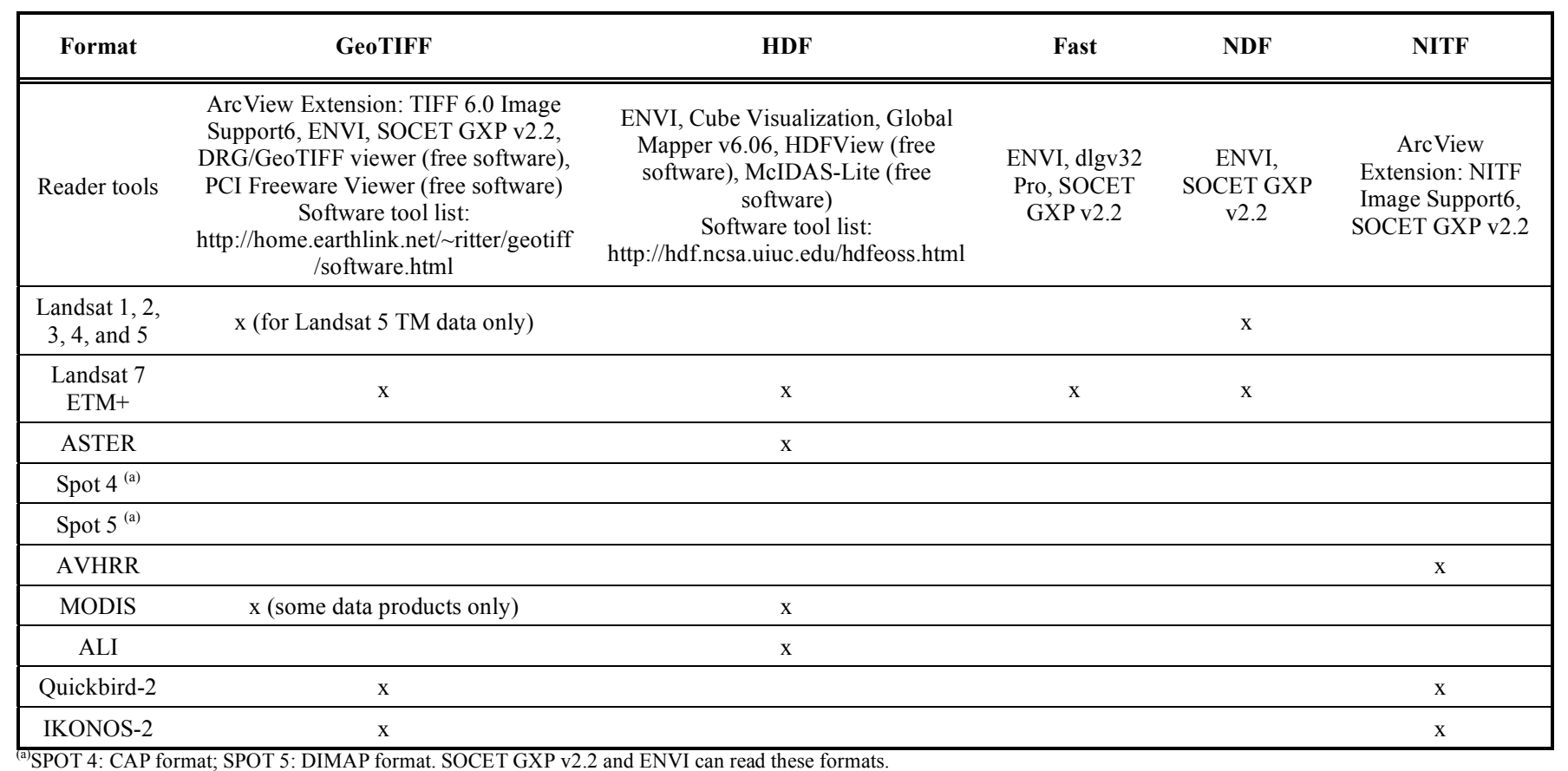


and foliar moisture and data transformations are often used as the preprocessed data for regression or other data analyses. Regression analysis between an index and a physical characteristic in the forest is a first approximation of the physical characteristic observed by the satellite data. Consequently, regression analyses have low coefficients of determination when using indices to predict plants' responses to changes in the environment. Future work should be based on the physiology of a plant's response to its environment as observed by the satellite, such as the surface temperature response of plants to moisture stress. However, indices and regression analyses still result in valuable information.

Plants absorb red light by chlorophyll and strongly reflect near infrared radiation by mesophyll tissue. Thus, near infrared reflectance will be high and red reflectance will be low for actively growing plants. Near infrared and red reflectance are commonly used in vegetation indices [1]. Researchers have proposed a number of spectral vegetation indices premised on the contrasts in spectral reflectance between green vegetation and background materials [10-13]. Of the indices, the Normalized Difference Vegetation Index (NDVI, [10]) is the most commonly utilized, and is based on infrared and red reflectance (Table 4). NDVI has been used for fuel mapping, foliar moisture stress detection, burn severity mapping, vegetation classification, forest type mapping, invasive weed detection, and land degradation modeling (Table 5).

Foliar moisture indices indicate leaf moisture. Because plant leaf moisture is related to the short wave infrared band [14], foliar moisture indices are formulated with the short wave infrared band and other bands (Table 4).

Burn indices, which detect burnt and burning areas, are usually formulated with near infrared and short wave bands. These two bands exhibit the greatest reflectance change in response to fire. Short wave reflectance increases with fire, while near infrared decreases [15]. The common burn index is the Normalized Burn Ratio (NBR, Table 4), which is widely used in burning detection and burn severity mapping (Table 5).

\subsection{Data Transformations}

Because of the low coefficient of variation between a satellite-derived index and a measured physical characteristic on the ground, two data transformation methods are often used in remote sensing of forest health: Principal Component Analysis (PCA) and Tasseled Cap Transformation (TCT). PCA is a classical statistical method equivalent to transforming the data to a new coordinate system with a new set of orthogonal axes, which reduces the information of the reflective bands into fewer useful vectors that explain the majority of the variation. The TCT, which is mathematically similar to the PCA but data independent $[16,17]$ and based on empirical observations, was performed on all images. TCT gets three major physical bands: wetness, brightness, and greenness.

\section{REMOTE SENSING APPLICATION IN FOREST HEALTH}

\subsection{Fire Fuel Mapping}

The type, composition, and distribution of fuels are the most important factors influencing fire hazard and fire risk [18]. Wildland fuels are typically divided into three strata: ground fuels, surface fuels, and crown fuels [19]. Remote sensing-based fuel mapping has typically employed one of the Landsat sensors to map fuel characteristics (Table 4) [20]. The Quickbird-2 and ASTER satellites have also been used for fuel mapping [21].

The common methods used in fuel mapping are regression methods and gradient modeling [21-23]. Gradient modeling refers to the use of environmental gradients (topographical, biogeochemical, biophysical, and vegetational) to model the occurrence of natural phenomena [22]. This approach has been used with moderate success in estimating fuel types and fuel loading. Environmental gradients such as topography, moisture, and time since last burn have a large impact on fuel loading [23]. High fuel loading, for example, can be partially explained by lower decomposition rates (characterized by moisture and temperature gradients) and a long time interval since the last fire [24].

The input parameters derived from satellite data for regression equations or gradient models are vegetation indices (Tables $\mathbf{3}$ and $\mathbf{4}$ ) and spectral transformations such as PCA and TCT. The outputs of fuel mapping usually are fuel load $\left(\mathrm{kg} / \mathrm{m}^{2}\right)$, canopy closure (percent cover), bulk density, canopy height, and vegetation types. The accuracy is around $50-85 \%$, even after using PCA or TCT analysis.

\subsection{Foliar Moisture Stress Detection}

Foliar moisture stress is mapped for fire risk assessment. Foliar moisture stress, or SMC (mass of foliar water per unit area), is defined as the total understory and overstory leaf moisture per unit area $\left(\mathrm{kg} \mathrm{H}_{2} \mathrm{O} / \mathrm{m}^{2}\right)$ [14]. Landsat, ASTER, and Spot have been used for foliar moisture prediction. Regression methods are the most commonly used methods of foliar moisture prediction $[25-30,14]$. The inputs were the components of TCT, PCA, vegetation indices, or foliar moisture indices (Tables 3 and $\mathbf{4}$ ). The $\mathrm{R}^{2}$ values range from 0.5 to 0.8 .

PCA is functional only for single-date analyses of foliar moisture, and cannot be used for monitoring forest health. Consequently, for periodic analysis and comparison, the weighted Normalized Difference of Infrared Index (wNDII) or TCT wetness are the most suitable approaches for estimating SMC [14].

\subsection{Fire Detection}

For forest fire detection, MODIS and AVHRR data and contextual algorithms are often used [31-36]. Contextual algorithms consider the local neighborhood of the pixel under examination to cope with variations in the background environmental temperature that may occur across the large area viewed by satellite systems [37].

Most of these algorithms use TIR bands at relatively short wavelengths around $4 \mu \mathrm{m}$ and long wavelengths around $11 \mu \mathrm{m}$ as the input data. Threshold values were set for these bands to detect fires. These algorithms require manual tuning of a series of thresholds according to the available spectral bands [37].

Li et al. [37] developed a hybrid algorithm based on previous contextual algorithms. The algorithm used multiple 
Table 4. Selected Indices and their Definitions Used in Remote Sensing for Forest Health

\begin{tabular}{|c|c|c|c|c|}
\hline Index Name & Acronym & Index Type & Definition $^{(a)}$ & References \\
\hline Normalized Difference Vegetation Index & NDVI & Vegetation & $\frac{\alpha_{\mathrm{NIR}}-\alpha_{\mathrm{R}}}{\alpha_{\mathrm{NIR}}+\alpha_{\mathrm{R}}}$ & [21] \\
\hline Simple Ratio & SR & Vegetation & $\frac{\alpha_{\mathrm{NIR}}}{\alpha_{\mathrm{R}}}$ & [21] \\
\hline Green-Red Ratio & GRVI & Vegetation & $\frac{\alpha_{\mathrm{G}}-\alpha_{\mathrm{R}}}{\alpha_{\mathrm{G}}+\alpha_{\mathrm{R}}}$ & {$[21]$} \\
\hline Modified Soil Adjusted Vegetation Index & MSAVI & Vegetation & $\frac{\alpha_{N I R}-\alpha_{R}}{\alpha_{N I R}+\alpha_{R}+L}(1+L)$ & [79] \\
\hline Enhanced Vegetation Index & EVI & Vegetation & $G \times \frac{\alpha_{N I R}-\alpha_{R}}{\alpha_{N I R}+c_{1} \alpha_{R}-c_{2} \alpha_{B}+l}$ & {$[80]$} \\
\hline Foliar Moisture Index & MI1 & Foliar moisture & $\frac{\alpha_{\mathrm{NIR}}}{\alpha_{\mathrm{R}} \alpha_{S W I R}}$ & [14] \\
\hline Foliar Moisture Index & MI2 & Foliar moisture & $\frac{\alpha_{\mathrm{NIR}}-\alpha_{\mathrm{R}}}{\left(\alpha_{\mathrm{NIR}}+\alpha_{\mathrm{R}}\right) \times \alpha_{S W I R}}$ & {$[14]$} \\
\hline Foliar Moisture Index & MI3 & Foliar moisture & $\frac{2.5\left(\alpha_{\mathrm{NIR}}-\alpha_{\mathrm{R}}\right)}{\left(1+\alpha_{\mathrm{NIR}}+6 \alpha_{\mathrm{R}}-7.5 \alpha_{\mathrm{B}}\right) \times \alpha_{\text {SWIR }}}$ & [14] \\
\hline Infrared Ratio Index & IRI & Foliar moisture & $\frac{\alpha_{\mathrm{NIR}}}{\alpha_{S W I R}}$ & [14] \\
\hline Normalized Difference Infrared Index & NDII & Foliar moisture & $\frac{\alpha_{\mathrm{NIR}}-\alpha_{\text {SWIR }}}{\alpha_{\mathrm{NIR}}+\alpha_{\text {SWIR }}}$ & [14] \\
\hline Wide-band Normalized Difference Infrared Index & wNDII & Foliar moisture & $\frac{2 \alpha_{\mathrm{NIR}}-\alpha_{S W I R}}{2 \alpha_{\mathrm{NIR}}+\alpha_{S W I R}}$ & {$[14]$} \\
\hline Global Vegetation Moisture Index & GVMI & Foliar moisture & $\frac{\left(\alpha_{N I R}+0.1\right)-\left(\alpha_{S W I R}+0.02\right)}{\left(\alpha_{N I R}+0.1\right)+\left(\alpha_{S W I R}+0.02\right)}$ & {$[29,30]$} \\
\hline Normalized Burn Ratio & NBR & Burn & $\frac{\alpha_{\mathrm{NIR}}-\alpha_{S W I R}}{\alpha_{\mathrm{NIR}}+\alpha_{S W I R}}$ & [45] \\
\hline Background (not burnt) Ratio & $\mathrm{BR}$ & Burn & $\frac{\alpha_{G}-\alpha_{T I R}}{\alpha_{G}+\alpha_{T I R}}$ & [37] \\
\hline NBR Change Index & $\mathrm{dNBR}$ & Burn & $N B R_{\text {Before }}-N B R_{\text {After }}$ & {$[45]$} \\
\hline Normalized Thermal Index & NTI & Burn & $\frac{R_{3.9}-R_{12}}{R_{3.9}+R_{12}}$ & [81] \\
\hline
\end{tabular}

(a) $\alpha_{\mathrm{NIR}}$ is the reflectance of near infrared band, $\alpha_{\mathrm{R}}$ is the reflectance of red band, $\alpha_{\mathrm{G}}$ is the reflectance of green band, $\alpha_{\mathrm{B}}$ is the reflectance of blue band, $\alpha_{\mathrm{SWIR}}$ is the reflectance of short wave infrared band, and $\alpha_{T I R}$ is the reflectance of thermal infrared band $L$ is a correction factor, which ranges from 0 for very high vegetation cover to 1 for very low vegetation cover.

$c_{1}$ : atmosphere resistance red correction coefficient.

$c_{2}$ : atmosphere resistance blue correction coefficient.

$l$ : canopy background brightness correction factor.

$G$ : gain factor.

The coefficients adopted in the EVI algorithm are: $l=1, c_{1}=6, c_{2}=7.5$, and $G$ (gain factor) $=2.5$ [80].

$N B R_{\text {Before }}$ and $N B R_{\text {Affer }}$ are NBR values before and after fires.

$R_{3.9}$ is the radiance of $3.9 \mu \mathrm{m}$ band and $R_{12}$ is the radiance of $12 \mu \mathrm{m}$ band.

bands (14 bands from MODIS) and the Normalized Thermal Index (NTI) (Tables 3 and 4). More importantly, it used the well-known squared Mahalanobis distance operating in multi-spectral feature space to identify fire pixels. This algorithm had better accuracy than previous algorithms. It worked when data from some bands were not available 
Table 5. Selected Studies of Satellite Remote Sensing for Forest Health. The Satellite, Band and Parameter Used, Method, and Accuracy are Provided

\begin{tabular}{|c|c|c|c|}
\hline $\begin{array}{l}\text { Study/ } \\
\text { Reference }\end{array}$ & Satellite/Band/Parameter & Method & Accuracy \\
\hline Fuel mapping [21] & ASTER/NIR, R, G/NDVI, GRVI, SR & $\begin{array}{l}\text { Regression and gradient } \\
\text { modeling }\end{array}$ & $\begin{array}{l}\mathrm{R}^{2}>77 \% \text { for canopy closure prediction, } \mathrm{R}^{2}>46 \% \text { for bulk density } \\
\text { prediction; the prediction of potential vegetation type agreed with } \\
\text { the local expert system. }\end{array}$ \\
\hline Fuel mapping [82] & $\begin{array}{c}\text { Landsat 5/R, G, B, NIR, SWIR/PCA } \\
\text { components 1, 2, and 3; brightness, } \\
\text { wetness and greeness of TCT, LAI, } \\
\text { MNDVI }\end{array}$ & $\begin{array}{l}\text { Regression and gradient } \\
\text { modeling }\end{array}$ & For fuel load prediction $\left(\mathrm{kg} / \mathrm{m}^{2}\right)$ accuracy from $51-85 \%$. \\
\hline $\begin{array}{l}\text { Foliar moisture stress } \\
{[14]}\end{array}$ & $\begin{array}{l}\text { Landsat } 5 \text { TM, ASTER/R, G, B, } \\
\text { NIR, SWIR/NDVI, SR, MI1, MI2, } \\
\text { MI3, IR, wNDII, PCA, TCT }\end{array}$ & Regression & $\begin{array}{l}\text { Correlation coefficients with SMC, PCA second component: } R^{2}= \\
0.765 \text {, wNDII: } R^{2}=0.627 \text {, TCT wetness: } R^{2}=0.638, R^{2} \text { for others } \\
\text { are around } 0.5-0.6 .\end{array}$ \\
\hline Fire detection [35] & $\begin{array}{l}\text { MODIS/TIR: } 3.66-4.08 \mu \mathrm{m}, 3.929- \\
3.989 \mu \mathrm{m}, 11.770-12.270 \mu \mathrm{m} ; \text { NIR: } \\
0.86 \mu \mathrm{m} / \text { temperature, reflectance }\end{array}$ & $\begin{array}{l}\text { Contextual and threshold } \\
\text { algorithms }\end{array}$ & $\begin{array}{l}\text { The detection algorithm is currently functioning reasonably well. } \\
\text { Some sensitivity to relatively small yet obvious fires has been } \\
\text { sacrificed to reduce persistent false detections occurring in regions } \\
\text { of hot, reflective, exposed soil. Nevertheless, some of these false } \\
\text { alarms remain. }\end{array}$ \\
\hline Fire detection [37] & $\begin{array}{l}\text { MODIS/fourteen TIR bands from } \\
3.660-14.085 \mu \mathrm{m} / \mathrm{NTI} \text {, radiance }\end{array}$ & Contextual algorithms & $84-100 \%$ \\
\hline $\begin{array}{l}\text { Post-fire burn area and } \\
\text { severity mapping [44] }\end{array}$ & $\begin{array}{l}\text { Landsat 5, Spot4, ASTER, } \\
\text { MODIS/NIR, SWIR, R/NBR, } \\
\text { dNBR, NDVI }\end{array}$ & Regression & $\begin{array}{l}\text { Correlation between the satellite parameters and burned severity. } \\
\qquad R^{2}: 44-79 \%\end{array}$ \\
\hline $\begin{array}{l}\text { Post-fire burn area and } \\
\text { severity mapping [42] }\end{array}$ & $\begin{array}{c}\text { Spot vegetation/NIR, SWIR/NBR, } \\
\text { NDVI }\end{array}$ & Spectral change detection & $>85 \%$ \\
\hline $\begin{array}{l}\text { Post-fire burn area and } \\
\text { severity mapping [45] }\end{array}$ & Landsat 7/NIR SWIR/dBNR & $\begin{array}{l}\text { Compare the BNR } \\
\text { difference before and } \\
\text { after fires }\end{array}$ & $73 \%$ \\
\hline $\begin{array}{c}\text { Vegetation } \\
\text { classification [52] }\end{array}$ & $\begin{array}{l}\text { Landsat/R, G, B, NIR, SWIR, } \\
\text { TIR/NDVI, PCA, TCT }\end{array}$ & $\begin{array}{c}\text { Unsupervised and } \\
\text { supervised algorithms }\end{array}$ & $\begin{array}{l}\begin{array}{l}\text { The forest/non-forest estimates are in close agreement with the FIA } \\
\text { data. }\end{array}\end{array}$ \\
\hline $\begin{array}{l}\text { Vegetation } \\
\text { classification [83] }\end{array}$ & $\begin{array}{l}\text { Landsat/R, G, B, NIR, SWIR, } \\
\text { TIR/N/A }\end{array}$ & $\begin{array}{l}\text { Unsupervised algorithm } \\
\text { and visual interpretation }\end{array}$ & $\begin{array}{l}\text { The forest } / \text { non-forest accuracy was } 83 \% \text {. The accuracy of no } \\
\text { change forest, forest loss, and forest gain were } 90 \%, 88 \% \text {, and } \\
92 \% \text {, respectively. }\end{array}$ \\
\hline $\begin{array}{l}\text { Vegetation } \\
\text { classification [51] }\end{array}$ & $\begin{array}{l}\text { Landsat } 5 / \mathrm{R}, \text { NIR, SWIR/spectral } \\
\text { signature }\end{array}$ & $\begin{array}{l}\text { Supervised spectral } \\
\text { classification }\end{array}$ & $75-98 \%$ \\
\hline $\begin{array}{l}\text { Landscape mapping } \\
\qquad 53]\end{array}$ & $\begin{array}{c}\text { Landsat/NIR SWIR, R, G, B/spectral } \\
\text { signature }\end{array}$ & Regression-trees & $\begin{array}{l}\text { Percent canopy average relative error was } 55 \% \text {, percent } \\
\text { impervious surface cover analysis had an average error of } 36 \% \text {. } \\
\text { The overall accuracy of this classification was } 99 \% \text {, from } \\
\text { classifying forest, non-forest, mixed, and water. }\end{array}$ \\
\hline $\begin{array}{l}\text { Landscape mapping } \\
{[84]}\end{array}$ & Landsat 7/NIR SWIR, R/N/A & Supervised classification & $82 \%$ \\
\hline Insect infestation [85] & Landsat 7/NIR SWIR, R, G, B/N/A & Supervised classification & $\begin{array}{l}\text { It was able to evaluate very broad categories of deciduous, } \\
\text { coniferous, and mixed forests, but could not determine the dead } \\
\text { trees infested by spruce bark beetles. }\end{array}$ \\
\hline $\begin{array}{c}\text { Forest type mapping } \\
{[86]}\end{array}$ & Spot/NIR SWIR, R/N/A & Supervised classification & $79-86 \%$ \\
\hline $\begin{array}{l}\text { Forest type mapping } \\
\text { [87] }\end{array}$ & $\begin{array}{l}\text { Landsat } 5 / \mathrm{NIR} \text { SWIR, R, G, B/TCT } \\
\text { wetness, brightness, greenness }\end{array}$ & $\begin{array}{l}\text { Gradient modeling using } \\
\text { inputs of TCT } \\
\text { components, climate, } \\
\text { topography, forest } \\
\text { ownership, geology, } \\
\text { location }\end{array}$ & $56-89 \%$ for the prediction of seven species. \\
\hline $\begin{array}{l}\text { Invasive weed } \\
\text { detection[88] }\end{array}$ & $\begin{array}{l}\text { Quickbird-2, IKONOS-2/B, G, R, } \\
\text { NIR/NDVI, other reflectance ratios } \\
\text { of G, R, NIR }\end{array}$ & Analysis of variance & $\begin{array}{l}\text { The values of NDVI and other indices of Ridolfia segetum were } \\
\text { significantly different from the values of bare soil, sunflowers. }\end{array}$ \\
\hline Forest vigor [3] & $\begin{array}{l}\text { Landsat 7/R, G, B, NIR, } \\
\text { SWIR/NDVI, TCT wetness and } \\
\text { greenness }\end{array}$ & $\begin{array}{l}\text { Change detection of the } \\
\text { indices }\end{array}$ & $\begin{array}{l}\text { Shows high potential for efficiently mapping and monitoring } \\
\text { vegetation change in a cost-effective manner. }\end{array}$ \\
\hline Biomass [58] & $\begin{array}{l}\text { Landsat/R, G, B, NIR, SWIR/NDVI, } \\
\text { other ratios of different bands }\end{array}$ & $\begin{array}{l}\text { Regression, neural } \\
\text { networks }\end{array}$ & $\mathrm{R}^{2}>50 \%$ \\
\hline Stand volume [89] & $\begin{array}{l}\text { Spot and Landsat/all bands/TCT, } \\
\text { NDVI, band ratios }\end{array}$ & Regression & $\mathrm{R}^{2}>31-44 \%$ \\
\hline $\begin{array}{l}\text { Land degradation } \\
\text { model [73] }\end{array}$ & MODIS/NIR, R/NDVI & $\begin{array}{l}\text { Integrated MODIS } \\
\text { vegetation index time } \\
\text { series data and spatially- } \\
\text { detailed climate data to } \\
\text { predict soil loss and } \\
\text { erosion }\end{array}$ & No ground truth comparison. \\
\hline
\end{tabular}


(e.g., sensor problems) because it could use other available bands. It can be tuned easily through a very small training set (four images).

There are problems detecting fires if the algorithms use only coarse-resolution data such as MODIS, or use only fineresolution data such as Landsat or Quickbird-2. Coarse data will not detect small fires, and fine-resolution data coverage is too small [38]. A combination of course- and fineresolution data may solve theses problems.

In addition to the above problems, current satellite sensors saturate at certain temperatures. For example, for MODIS sensors the commonly used bands for fire detection are $1.65 \mu \mathrm{m}, 2.13 \mu \mathrm{m}, 4 \mu \mathrm{m}$, and $11 \mu \mathrm{m}$, with saturation temperatures of $740 \mathrm{~K}, 570 \mathrm{~K}, 500 \mathrm{~K}$, and $400 \mathrm{~K}$, respectively [39]. However, forest fires can reach temperatures as high as $1800 \mathrm{~K}$ [40], which can sterilize the soil and make post-fire vegetation recovery difficult. Sensors and algorithms for estimating high temperatures need to be developed in order to estimate fire damage more precisely.

\subsection{Post-Fire Burned Area Mapping}

After forest fires, the burn area and burn severity need to be mapped to help rehabilitation. The most commonly used parameters for estimates of burn severity and area are Normalized Burn Ratio (NBR), dNBR, and NDVI (Table 5). Usually, researchers use these indices with a threshold value or a regression equation to predict the burn area and burn severity (Table 6) [41-45]. In addition, some researchers observe temporal differencing of spectral transformation (TCT) to detect the burned area [46, 47].

Lieberman et al. [47] examined the use of satellite multispectral imagery to map three levels of fire severity within two southern California fire scars. They compared the effects of spectral transformation, temporal dimensionality, classifiers, and satellite sensor types on the ability to accurately map wildfire severity when field data were used for training. Temporal differencing of the TCT on Landsat Thematic Mapper (TM) imagery was the most accurate of all approaches and image types tested for both burn sites. The classification maps derived from NBR, spectral transformations on TM imagery, and non-enhanced IKONOS-2 multi-spectral images resulted in the lowest accuracies.

\subsection{Mapping of Vegetation, Landscape, Insect Infestation, and Invasive Weeds}

Vegetation and landscape mapping (including insect infestation and invasive weed mapping, both types of vegetation mapping) used image classification algorithms. There are two general types of classification algorithms: supervised and unsupervised [48-52, 1, 2]. In supervised classification, known spectral reflectance values, derived either from known locations on the image or from handheld spectrometers, are used to identify other pixels having the same reflectance. In unsupervised classification algorithms, a computer recognizes different patterns and classifies them into different vegetation or land cover categories. In general, supervised classification is more accurate than unsupervised. The classification software packages of eCognition (Definiens Inc., Boston, MA), Feature Analyst (Visual Learning System, Inc., Missoula, MT), and ERDAS Imagine
(Geosystems Geospatial Imaging, LLC, Norcross, GA) have been commonly used for vegetation classification and mapping [53].

Regression-tree classification is a relatively new procedure for land cover classification. Regression-tree classification procedures have several advantages over more traditional classification procedures such as supervised and unsupervised algorithms. Regression-trees are nonparametric and, as such, do not require knowledge about data distributions and can handle non-linear relationships between variables. They can also allow for missing data values, handle both numerical and categorical data, and incorporate multiple remote sensing and GIS data layers. Regression-tree classifications are significantly less labor-intensive than other classification techniques and can be used efficiently for large land cover classifications. Accuracies of regression-tree classifications are either similar to or better than supervised and unsupervised classification [53].

For the mapping of vegetation, landscape, insect infestation, and invasive weeds, the input data from satellites are usually NDVI, Enhanced Vegetation Index (EVI), Modified Soil Adjusted Vegetation Index (MSAVI), TCT brightness, greenness, wetness, elevation, aspect, and slope. The outputs are percent canopy cover, forest/non-forest classification, and tree types (Table 4). The accuracy was between $50 \%$ and $99 \%$, and depended on the predictor variable selection and dependent variable type. For example, the forest/non-forest classification (dependent variable) obtained the highest accuracy among all types of classifications.

\subsection{Forest Vigor}

Cost effective methods are necessary for broad-scale regular assessment of forest vigor over complex terrain. Satellite-derived vegetation indices such as NDVI can monitor large remote areas with an effective database for evaluating vegetation vigor.

High percentages of spectral variance in individual scenes can be explained using TCT [54]. The TCT greenness and wetness bands have a strong correlation to the percentage of vegetation cover [17]. The greenness feature measures the presence and density of green vegetation while the wetness feature measures soil moisture content and vegetation density [17].

For example, Beck and Gessler [3] proposed methods for mapping and monitoring forest status through the creation of maps that show departure from average NDVI, TCT greenness, and TCT wetness indices derived from an expanding time-series of Landsat imagery. Methods for displaying negative and positive departures were presented and evaluated for significance in support of forestland management. Current departure classification clearly delineates major disturbances such as roads and forest harvest activities within the negative departure from the average.

\subsection{Stand Volume and Biomass}

Satellite data of high-resolution [55], medium-resolution (Landsat; [56-59]) and coarse-resolution (MODIS, AVHRR, 
and Spot; [60-62]) have been used for forest biomass estimation.

Researchers have used multiple regression analysis, $\mathrm{K}$ nearest-neighbor, and neural network mapping to estimate above-ground biomass [62-65, 57-59, 21]. Compared with vegetation classification (e.g., percent canopy cover), forest stand volume and biomass estimation were less accurate (Table 4). The $\mathrm{R}^{2}$ is usually below $50 \%$. The most commonly used method of biomass estimation is regression using vegetation indices as the inputs. The low accuracy may be due to the weak relationship between the dependent variables (biomass and volume) and the predictor variables (e.g., NDVI).

Lu [65] reviewed current studies about biomass remote sensing. He concluded that biomass estimation remains a challenging task, especially in those study areas with complex forest stand structures and environmental conditions.

Biomass estimation has also been used in rangeland management. For example, Gillham and Mellin [66] conducted temporal image analysis to assist rangeland managers in assessing range readiness, monitoring utilization levels, and making decisions to extend or shorten the length of the grazing season. Landsat TM and ETM+ images were used to develop correlations between the field-gathered data (dry biomass weight per unit area) and remotely-sensed imagery. The overall $\mathrm{R}^{2}$ was 0.68 . MODIS satellite images were used to develop a series of greenness indices throughout the growing season but were not directly correlated with field data.

\subsection{Forest ET and Carbon Fluxes}

Forest water stress, biomass, and growth (including fuel level and forest vigor) are highly related to fire and insect risks. However, there have been few studies on forest ET (forest water stress indicator) and biomass growth predictions. Previous studies estimated forest water stress (foliar moisture) using regression equations from inputs of vegetation and moisture indices or PCA- and TCTtransformed data $[29,30,14]$. Regression equations may produce errors for different locations and environmental conditions. Physically- and physiologically-based models need to be developed for the water stress calculation. ET models using the energy balance principle for agriculture fields (level-ground) are available with high accuracy [67, $68,4,8]$. The typical accuracy at field scale is $85 \%$ for 1 day, and increases to $95 \%$ on a seasonal basis [4]. The physiological relationship between ET and biomass growth has been obtained from physiological models [69]. Therefore, the biomass growth can be calculated from modeled ET.

The difficulty in mapping forest ET and biomass growth is to correct the effects from elevation, slope, and aspect, which cause surface temperature and radiation variations and can result in errors of ET estimations using energy balance methods [9]. Morse et al. [70] tried to correct this surface temperature effect by assuming a $6.5^{\circ} \mathrm{C} / \mathrm{km}$ lapse rate. However, this lapse rate was for air temperature, which may not be the lapse rate for the surface temperature. Further work, including experiments and models, is needed to calibrate and validate elevation, aspect, and slope effects on ET calculation.

\subsection{Data Management Tools}

Several studies have focused on data management for the satellite remote sensing of forest health (e.g., [71]). The purpose of these studies is to allow users to more conveniently and quickly find and obtain the desired data. Most of these data management tools are web-based.

For example, the FSGeodata Clearinghouse at the USFS allows users to search, view, and download geospatial datasets and metadata created and maintained by the Forest Service. Access to datasets is provided through a user-driven geographic interface. It provides geospatial data, National Forest Lands Cartographic Feature Files, National Forest Lands Raster 1:24 000 Map Files, real-time and near realtime MODIS fire detection GIS data, MODIS fire detection maps, MODIS imagery, and other related fire geospatial data for the U.S. and Canada. Fig. (1) is a sample MODIS Active Fire Detection map for the southwestern U.S. on June 9, 2006.

The U.S. Geological Survey (USGS) also provides a web-based fire data ordering system for use in wildfire applications for GIS technical specialists, infrared interpreters, and fire managers. The application at USGS allows for an interactive display of maps integrated with current wildfire information, and is enhanced with the capability to process, reproject, mosaic, and tone balance Digital Raster Graphics, Digital Orthophoto Quads, and Digital Elevation Models. The application can automatically disseminate the data for users to download, or deliver the data on CD-ROM using various mail delivery methods.

In addition, the Goddard Space Flight Center and the University of Maryland built a web-based, real-time automated global fire detection system using MODIS products, and the Cooperative Institute for Meteorological Satellite Studies (CIMSS) at the University of WisconsinMadison has used the Geostationary Satellite (GOES) series of satellites to monitor fires and smoke in the western hemisphere.

The USFS provides Forest Inventory and Analysis (FIA) data that are used to monitor tree growth and harvests, tree species, land use patterns, forested wildlife habitat, mortality, and other forest health attributes, as well as regional biological processes, timber and non-timber forest products, and associated human activities. These data files are compressed; comma separated, and can be easily uploaded into spreadsheets.

The Arizona Remote Sensing Center in the Office of Arid Lands Studies at the University of Arizona provides a web-based geospatial application (RangeView) for viewing, animating, and analyzing multi-temporal satellite and precipitation data to monitor vegetation dynamics over time and across landscapes. RangeView has been developed for natural resource managers, but also has significant value for educators and researchers. MODIS-derived products have been developed and integrated to facilitate monitoring and interpretation of vegetation growth, drought, and wildfire dynamics. The MODIS-derived products include spectral vegetation indices (in $250 \mathrm{~m}$ and $1 \mathrm{~km}$ resolutions) and a 


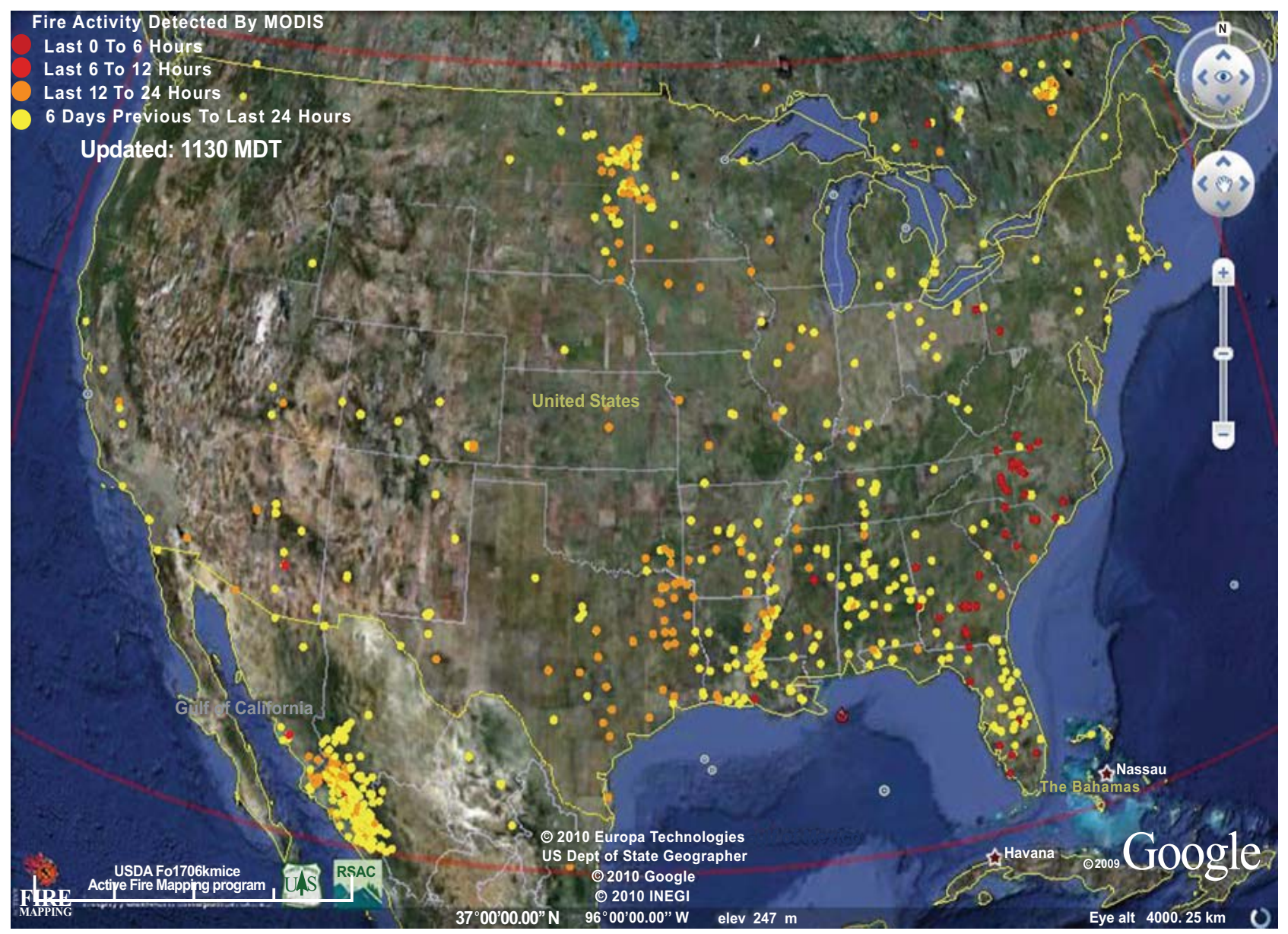

Fig. (1). A sample MODIS Active Fire Detection map for the southwestern US on June 9, 2006. Downloaded from the USFS Geodata Clearinghouse at http://svinetfc4.fs.fed.us/.

prototype of associated cloud and snow cover data. A color composite image is also provided to help assess the quality of the NDVI data.

The MODIS-derived Leaf Area Index (LAI) is provided as an additional indicator of live vegetation. Fig. (2) shows the western U.S. MODIS LAI maps in January, February, March, and April of 2006.

The USFS Pacific Northwest Region developed a toolkit of terrestrial ecological unit inventories (TEUI-Geospatial Toolkit) [72]. A primary objective of the TEUI-Geospatial Toolkit is to implement national inventory protocols and provide an efficient and repeatable method for conducting TEUI at the landscape and land unit scale. The toolkit combines geospatial data preparation, visualization; onscreen digitization, map unit analysis, and field-sheet map production tools in a step-by-step and user-friendly format. Using the TEUI-Geospatial Toolkit, a resource specialist controls the entire mapping process from data loading to concept development to landscape stratification. The toolkit was field verified and found to be very effective for predicting soil patterns and distribution across the study area.

The above studies illuminate the major operational tools for satellite remote sensing of forest health. Most of the other studies described in this paper have not provided operational tools for forest health managers.

\subsection{Other Studies}

There have been some studies in land degradation modeling and hydrology. For example, van Leeuwen and Sammons [73] used MODIS products and data integration methods to assess land degradation and rehabilitation, and to incorporate seasonal and geospatial vegetation and climate products into two soil erosion assessment models. The Revised Universal Soil Loss Equation (RUSLE) model was used to assess monthly soil loss. MODIS-based NDVI was used to derive monthly vegetation cover and vegetation resistance to soil erosion. No ground truth comparison was conducted in this study. 

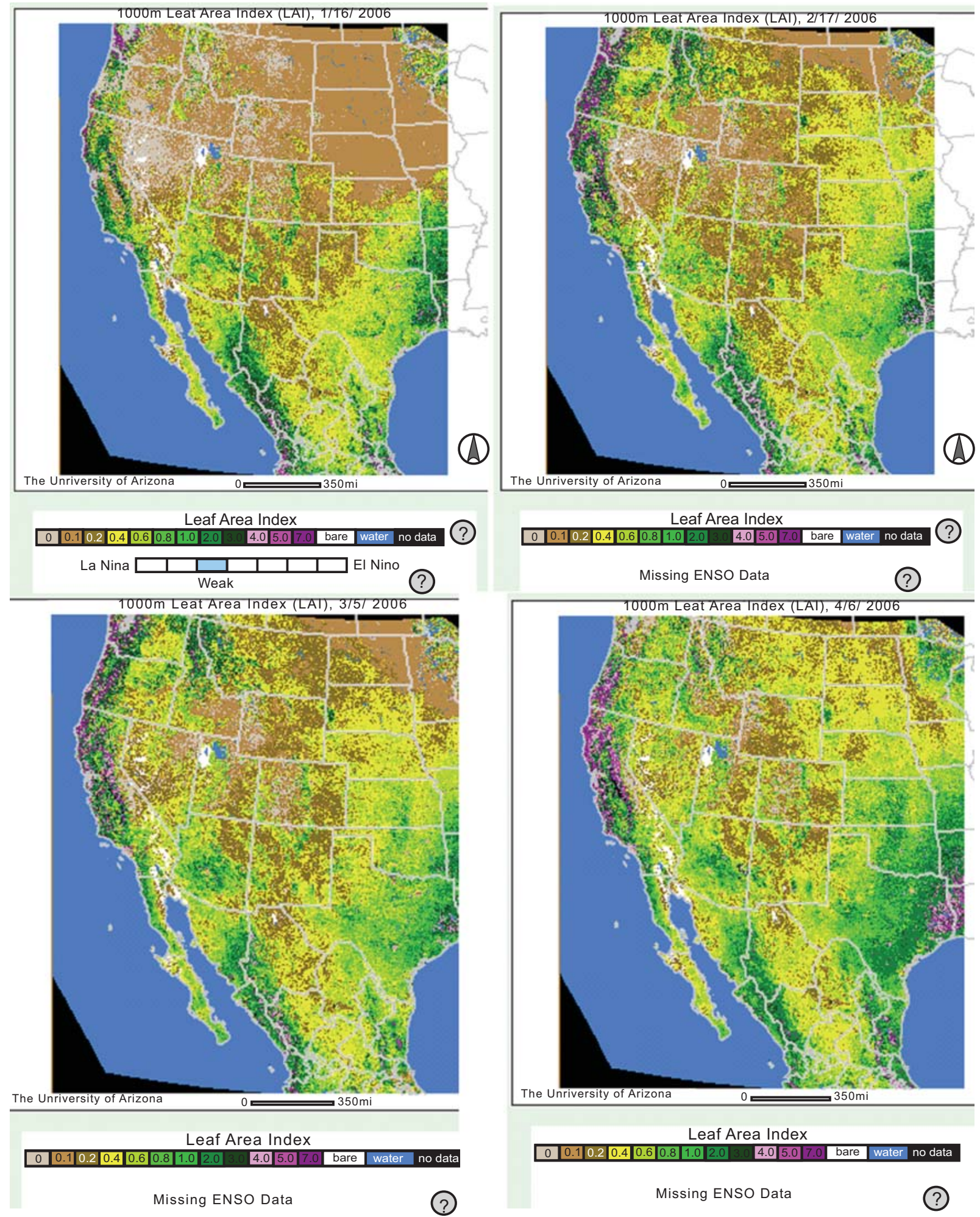

Fig. (2). Western US LAI maps in January (top left), February (top right), March (bottom left), and April (bottom right) of 2006. Downloaded from the Arizona Remote Sensing Center, Office of Arid Lands Studies, University of Arizona at http://rangeview.arizona.edu

\section{FUTURE WORK}

\subsection{Sensors}

The current satellite sensor capabilities are impressive, yet some additional sensors are needed. For example, current satellite TIR sensors saturate at low fire temperatures and therefore cannot distinguish the very high temperature fires from lower temperature fires, which is important to estimate fire damage and post-fire vegetation recovery.

Several indicators of the physiological state of vegetation require narrow bandwidths $(5 \mu \mathrm{m}$ or less) that are not measured by current satellite sensors. For example, the narrow bands of the green wavelength can be used to directly 
calculate carbon flux using the photochemical reflectance index

$\left(\alpha_{531}-\alpha_{570}\right) /\left(\alpha_{531}+\alpha_{570}\right)$,

where $\alpha_{531}$ and $\alpha_{570}$ are the reflectance of narrow bands with wavelengths $531 \mu \mathrm{m}$ and $570 \mu \mathrm{m}$, respectively. The index exhibits a high correlation to ground measurements via gas exchange on leaves or via flux towers [73-75].

Another example is the water index, particularly

$\alpha_{900} / \alpha_{970}$,

where $\alpha_{900}$ and $\alpha_{970}$ are the reflectance of narrow bands with wavelengths $900 \mu \mathrm{m}$ and $970 \mu \mathrm{m}$, respectively. This index effectively measures column density of water in canopy leaves [77].

A final example is the chlorophyll index. The index, originally posited as

$\left(\alpha_{750}-\alpha_{705}\right) /\left(\alpha_{750}+\alpha_{705}\right)$,

where $\alpha_{750}$ and $\alpha_{705}$ are the reflectance of narrow bands with wavelengths $750 \mu \mathrm{m}$ and $705 \mu \mathrm{m}$, respectively, has been refined to achieve high fidelity to actual chlorophyll content, which can then be related to biomass growth [78].

\subsubsection{Physical Models for Biophysical Attributes}

The limitations to inferring forest biomass, stress, water use, and other attributes have been noted earlier. For example, because forest water stress strongly affects forest health, which can increase the risk of fires and insect outbreaks, work was done to monitor forest water stress using NDVI and other indices. However, regression equations using only these indices may not be accurate for other locations and environmental conditions.

Physical models are needed. ET is an indicator of forest water stress and may be estimated using satellite remote sensing using a physical model (e.g., energy balance model) $[9,4-6]$. Because a remote sensing model of level-field ET is available, the major work to adapt this model to forests will be to incorporate the effects of the elevation, aspect, and slope of mountain areas.

As another example, a physical method must be developed to predict biomass growth. There was some work on forest biomass or growth estimation, which is related to fire fuel mapping. NDVI and other vegetation indices were used to predict biomass and growth using regression equations. The accuracy of the equation will be affected by environmental factors, especially illuminations. A more stable method must be developed to predict biomass growth. Because biomass growth is highly related to ET, biomass growth can be estimated using appropriate adjustments from an ET map obtained from remote sensing [69].

\subsection{Data Management Tools}

Most forest management tools are user-friendly. However, some tools require operators who are expert-level researchers. These tools are not appropriate for forest managers. Some tools require the user to operate different software packages step-by-step to obtain results. In addition, some web-based forest health tools provide only maps, with no grid data available. The above needs to be improved in the future.

\section{CONCLUSIONS}

Current and previous satellite remote sensing applications for determining forest health have focused on the following categories: vegetation and landscape classification, biomass mapping, invasive plants detection, fire fuel mapping, canopy or foliar water stress, fire detection and progression mapping, post-fire burn area and severity mapping, and insect infestation detection. The USFS is the lead agency in forest status and health studies using satellite remote sensing. The major satellite sensors used for remote sensing of forest health are ASTER, ALI, MODIS, Landsat $5 \mathrm{TM}$ and Landsat $7 \mathrm{ETM}+$, Spot 4 and 5, Quickbird-2, and IKONOS-2. The majority of studies have analyzed spectral signatures or simple indices (calculated from reflectance data) such as NDVI. Correlation and regression methods are the most commonly used research methods.

Among the satellite sensors, MODIS data are more appropriate than other satellite data for most of the remote sensing applications for forest health because of their temporal and spatial resolutions, cost, and bands. MODIS has a 1-2 day temporal and a $250-1000 \mathrm{~m}$ spatial resolution; the data are free and cover more bands than other satellites (36 bands total).

Physical and physiological modeling (e.g., ET and biomass growth) must be developed to improve remote sensing of forest health. In addition, some satellite sensors, such as for high temperature estimates (as high as $1800 \mathrm{~K}$ ) and sensors of narrow bands, are needed to provide more accurate measurements for a wide range of variables.

\section{ACKNOWLEDGEMENTS}

This work was supported with funds from the USFS under contract 05-CA-11244225-279, the New Mexico State University Agricultural Experiment Station, and the U.S. Department of Agriculture's Rio Grande Basin Initiative. Special thanks to graduate research assistant Mr. Scott Williams for his literature collection assistance.

\section{REFERENCES}

[1] Campbell JB. Introduction to remote sensing. The Guilford Press: New York 2002.

[2] Foody GM. Status of land covers classification accuracy assessment. Remote Sens Environ 2002; 80: 185-201. [doi:101016/S00344257(01)00295-4].

[3] Beck RN, Gessler PE. Forest vigor assessment of the inland northwest using Landsat timeseries. Proc of the 10th Biennial Forest Svc: Remote Sensing App Conf 2004. [doi:101061/(ASCE)0733-9437(2005)131: $1(85)]$.

[4] Bastiaanssen WGM, Noordman EJM, Pelgrum H, Davids G, Thoreson BP, Allen RG. SEBAL model with remotely sensed data to improve water-resources management under actual field conditions. J Irrig Drain Eng 2005; 131: 85-93.

[5] French AN, Jacob F, Anderson MC, et al. Surface energy fluxes with the Advanced Spaceborne Thermal Emission and Reflection radiometer (ASTER) at the Iowa 2002 SMACEX site (USA), Remote Sens Environ 2005; 99: 55-65. [doi:101016/jrse200505015]

[6] Kustas WP, Norman JM. A two-source energy balance approach using directional radiometric temperature observations for sparse canopy covered surfaces. Agron J 2000; 92: 847-54.

[7] Clark J, Zajkowski T, Lannom K. Remote sensing imagery support for burned area emergency response teams on 2003 southern California wildfires. Proc of the $10^{\text {th }}$ Biennial Forest Svc: Remote Sensing App Conf 2004.

[8] Wang J, Sammis TW, Meier CA, Simmons LJ, Miller DR, Samani Z. A modified SEBAL model for spatially estimating pecan consumptive 
water use for Las Cruces, New Mexico, in 15th Conf on Applied Climatology 2005.

[9] Wang J, Sammis TW, Meier CA, Simmons LJ, Miller DR, Bathke D. Remote sensing vegetation recovery after forest fires using energy balance, presented at sixth symposium on fire and forest meteorology, 25-27 October 2005, Canmore, AB, Canada, Paper 76, American Meteorological Society.

[10] Rouse JW, Haas RH, Deering DW, Sehell JA. Monitoring the vernal advancement and retrogradation (green wave effect) of natural vegetation, Final Report RSC 1978-4. Remote Sensing Center, Texas A\&M Univ: College Station 1974.

[11] Richardson AJ, Wiegand CL. Distinguishing vegetation from soil background information. Photogramm Eng Remote Sensing 1977; 43: 1541-52.

[12] Tucker CJ. Red and photographic infrared linear combinations for monitoring vegetation. Remote Sensing Environ 1979; 8: 127-50. [doi:101016/0034-4257(79)90013-0].

[13] Jackson RD. Spectral indices in n-space. Remote Sens Environ 1983; 13: 409-21. [doi:101016/0034-4257(83)90010-X].

[14] Toomey M, Vierling LA. Multispectral remote sensing of landscape level foliar moisture: techniques and applications for forest ecosystem monitoring. Can J For Res 2005; 35(5): 1087-97. [doi:101139/x05-043]

[15] Key CH, Benson NC. Measuring and remote sensing of burn severity. Second US Geological Survey Wildland Fire Workshop 2002; pp. 55.

[16] RJ Kauth, Thomas GS. The tasseled cap: a graphic description of the spectral-temporal development of agricultural crops as seen by Landsat. Proc of the Symposium on Machine Processing of Remotely Sensed Data 1976; pp. 41-50.

[17] Crist EP, Laurin R, Cicone RC. Vegetation and soils information contained in transformed thematic mapper data, in Proceedings of IGARSS' 1986 Symposium 1986.

[18] Chuvieco E, Congalton RG. Application of remote sensing and geographic information systems to forest fire hazard mapping. Remote Sens Environ 1989; 29: 147-59. [doi:101016/0034-4257(89)90023-0].

[19] Pyne SJ, Andrews PL, Laven RD. Introduction to Wildland Fire. John Wiley and Sons Inc.: New York 1996.

[20] Riano D, Meier E, Allgower B, Chuvieco E, Ustin SL. Modeling airborne laser scanning data for the spatial generation of critical forest parameters in fire behavior modeling. Remote Sens of Environ 2003; 86: 177-86. [doi:101016/S0034-4257(03)00098-1].

[21] Falkowski MJ, Gessler PE, Morgan P, Hudak AT, Smith AMS. Characterizing and mapping forest fire fuels using ASTER imagery and gradient modeling. For Ecol Manage 2005; 217(2-3): 129-46. [doi:101016/jforeco200506013].

[22] Keane RE, Mincemoyer SA, Schmidt KM, Long DG Garner, JL. Mapping vegetation and fuels for fire management on the Gila National Forest Complex, New Mexico, General Technical Report RMRSGTR46- CD, US Department of Agriculture Forest Service, Rocky Mountain Research Station, Ogden, Utah, 2002; pp. 1-126.

[23] Kessell SR. Gradient modeling: resource and fire management. Springer Verlag: New York 1979.

[24] RE Keane, R Burgan, J van Wagtendok. Mapping wildland fuels for fire management across multiple scales: integrating remote sensing, GIS, and biophysical modeling. Int J Wildland Fire 2001; 10: 301-19. [doi:101071/WF01028].

[25] Tucker CJ. Remote sensing of leaf water content in the near infrared. Remote Sensing of Environment. Proc of the 2004 10th Biennial Forest Svc Remote Sensing App Conf 2004; pp. 23-32.

[26] Hunt ER Jr, Rock BN. Detection of changes in leaf water content using near- and middle-infrared reflectances. Remote Sens Environ 1989; 30: 43-54. [doi:101016/0034-4257(89)90046-1].

[27] Downing HG, Carter GA, Holladay K, Cibula WG. The radiativeequivalent water thickness of leaves. Remote Sens Environ 1993; 46: 103-07. [doi:101016/0034-4257(93)90035-V].

[28] Ceccato P, Flasse S, Tarantola S, Jacquemoud S, Grégoire JM. Detection vegetation leaf water content using reflectance in the optical domain. Remote Sens Environ 2001; 77: 22-3. [doi:101016/S00344257(01)00191-2].

[29] Ceccato P, Gobron N, Flasse S, Pinty B, Tarantola S. Designing a spectral index to estimate vegetation water content from remote sensing data, Part 1. Remote Sens Environ 2002; 82: 188-97. [doi:101016/S0034-4257(02)00037-8].

[30] Ceccato P, Flasse S, Gregoire JM. Designing a spectral index to estimate vegetation water content from remote sensing data, Part 2. Remote Sens Environ 2002; 82: 198-207. [doi:101016/S00344257(02)00036-6].
[31] Flasse SP, Ceccato P. A contextual algorithm for AVHRR fire detection. Int J Remote Sensing 1996; 17: 419-24. [doi:101080/01431169608949018].

[32] Justice C, Kendall JD, Dowty PR, Scholes RJ. Satellite remote sensing of fires during the SAFARI campaign using NOAA advanced very high resolution radiometer data. J Geophy Res 1996; 101: 23851-64. [doi:101029/95JD00623].

[33] Kaufman YJ, Justice CO, Flynn LP, et al. Potential global fire monitoring from EOS-MODIS. J Geophy Res 1998; 103: 32215-38. [doi:101029/98JD01644].

[34] Giglio L, Kendall JD, Justice CO. Evaluation of global fire detection algorithms using simulated AVHRR infrared data. Int J Remote Sensing 1999; 20: 1947-85. [doi:101080/014311699212290].

[35] Justice CO, Giglio L, Korontzi S, et al. The MODIS fire products. Remote Sens Environ 2002; 83: 245-63. [doi:101016/S00344257(02)00076-7].

[36] Giglio L, Descloitres J, Justice CO, Kaufman YJ. An enhanced contextual fire detection algorithm for MODIS. Remote Sens Environ 2003; 87: 273-82. [doi:101016/S0034-4257(03)00184-6].

[37] Li Y, Vodacek A, Kremens RL, Ononye A, Tang C. A hybrid contextual approach to wildland fire detection using multispectral imagery. IEEE Transactions on Geoscience and Remote Sensing 2005; 43(9): 2115-26. [doi:101109/TGRS2005853935].

[38] Kaufman YJ, Setzer AW, Justice CO, Tucker CJ, Pereira MC, Fung I. Remote sensing of biomass burning in the tropics. J G Goldammer, Ed. Fire in the Tropical Biota, Springer-Verlag: Berlin 1990; pp.400-17.

[39] Kaufman YJ, Justice C. Algorithm technical background document (Version 22 Nov 10 1998), MODIS Fire Products (EOS ID\# 2741) (1998).

[40] Boyd DS, Danson FM. Satellite remote sensing of forest resources: three decades of research development. Prog Phys Geogr 2005; 29(1): 1-26. [doi:101191/0309133305pp432ra].

[41] Salvador R, Valeriano J, Pons X, Díaz-Delgado R. A semiautomatic methodology to detect fire scars in shrubs and evergreen forests with Landsat MSS time series. Int J Remote Sensing 2000; 21: 655-73. [doi:101080/014311600210498].

[42] Fraser RH, Li Z. Estimating fire-related parameters in boreal forest using spot vegetation. Remote Sens Environ 2002; 82: 95-110. [doi:101016/S0034-4257(02)00027-5].

[43] Hudak AT, Brockett BH. Mapping fire scars in a southern African savannah using Landsat imagery. Int J Remote Sensing 2004; 25: 3231 43. [doi:101080/01431160310001632666].

[44] Hudak AT, Robichaud PR, Evans JB. Field validation of burned area reflectance classification (BARC) products for post fire assessment. Proc of the 2004 10th Biennial Forest Svc. Remote Sensing App Conf 2004.

[45] Cocke AE, Fulé PZ, Crouse JE. comparison of burn severity assessments using differenced normalized burn ratio and ground data. Int J Wildland Fire 2005; 14: 189-98. [doi:101071/WF04010].

[46] Rogan J, Yool SR. Mapping fire-induced vegetation depletion in the Peloncillo Mountains, Arizona and New Mexico. Int J Remote Sensing 2001; 22(16): 3101-21. [doi:101080/01431160152558279].

[47] Lieberman AR, Stow D, Rogan J, Franklin J. Mapping burn severity in southern California Mediterranean type vegetation using Landsat and IKONOS data. Proc of the 2004 10th Biennial Forest Svc Remote Sensing App Conf 2004.

[48] Brown SA, Hall CAS, Knabe W, Raich J, Trexler MC, Woomer P. Tropical forests, their past, present and potential future role in the terrestrial carbon budget. Water Air Soil Pollut 1993; 70: 71-94. [doi:101007/BF01104989].

[49] Jensen JR. Introductory Digital Image Processing, Prentice Hall, Upper Saddle River: NJ 1996.

[50] Saatchi SS, Rignot E. Classification of boreal forest cover types using SAR images. Remote Sens Environ 1997; 60: 270-81. [doi:101016/S0034-4257(96)00181-2].

[51] Steininger MK, Tucker CJ, Ersts P, Killeen TJ, Villegas Z, Hecht SB. Clearance and fragmentation of tropical deciduous forest in the Tierras Bajas, Santa Cruz, Bolivia. Conserv Biol 2001; 15: 856-66. [doi:101046/j1523-17392001015004856x].

[52] Hoppus M, Lister AJ. Measuring forest area loss over time using FIA plots and satellite imagery. Proc of the 2002 FIA Symposium/Annual Meeting of the Southern Mensurationists 2005; pp. 91-7.

[53] Ruefenacht B. Use of regression-trees in remote sensing. Proc of the 2004 10th Biennial Forest Svc Remote Sensing App Conf 2004.

[54] Huang C, Wylie B, Yang L, Homer C, Zylstra G. Derivation of a tasseled cap transformation based on Landsat 7 at-satellite reflectance. 
Int J Remote Sensing 2002; 23(8): 1741-8. [doi:101080/014311601101 06113]

[55] Thenkabail PS, Stucky N, Griscom BW, et al. Biomass estimations and carbon stock calculations in the oil palm plantations of African derived savannas using IKONOS data. Int J Remote Sensing 2005; 25(23): 5447-72. [doi:101080/01431160412331291279]

[56] Lu D. Above ground biomass estimation using Landsat TM data in the Brazilian Amazon. Int J Remote Sensing 2005; 26: 2509-25. [doi:101080/01431160500142145]

[57] D Zheng, Rademacher J, Chen J, et al. Estimation aboveground biomass using Landsat $7 \mathrm{ETM}+$ data across a managed landscape in northern Wisconsin, USA. Remote Sens Environ 2004; 93: 402-11. [doi:101016/jrse200408008]

[58] Foody GM, Boyd DS, Cutler MEJ. Predictive relations of tropical forest biomass from Landsat TM data and their transferability between regions. Remote Sens Environ 2003; 85: 463-74. [doi:101016/S00344257(03)00039-7]

[59] Steininger MK. Satellite estimation of tropical secondary forest above ground biomass data from Brazil and Bolivia. Int J Remote Sensing 2000; 21: 1139-57. [doi:101080/014311600210119]

[60] Baccini A, Friedl MA, Woodcock CE, Warbington R. Forest biomass estimation over regional scales using multisource data. Geophys Res Lett 2004; 31: 1-4. [doi:101029/2004GL019782]

[61] Dong J, Kaufmann RK, Myneni RB, et al. Remote sensing estimates of boreal and temperate forest woody biomass: Carbon pools, sources and sinks Remote Sens Environ 2003; 84: 393-410. [doi:101016/S00344257(02)00130-X]

[62] Roy PS, Ravan SA. Biomass estimation using satellite remote sensing data-An investigation on possible approaches for natural forest. $\mathbf{J}$ Bioscience 1996; 21, 515-61. [doi:101007/BF02703218]

[63] Nelson RF, Kimes DS, Salas WA, Routhier M. Secondary forest age and tropical forest biomass estimation using thematic mapper imagery. Bioscience 2000; 50: 419-31. [doi:101641/00063568(2000)050[0419:SFAATF]20CO;2]

[64] Moisen GG, Blackard JA, Finco M. Small area estimation in forests affected by wildfire in the interior west. Proc of the 2004 10th Biennial Forest Svc Remote Sensing App Conf 2004.

[65] Lu D. The potential and challenge of remote sensing-based biomass estimation. Int $\mathrm{J}$ Remote Sensing 2006; 27(7): 1297-328. [doi:101080/01431160500486732].

[66] Gillham J, Mellin TC. Monitoring rangeland trends using remote sensing. Proc of the 2004 10th Biennial Forest Svc Remote Sensing App Conf 2004.

[67] Bastiaanssen WGM, Menenti M, Feddes RA, Holtslag AAM. A remote sensing surface energy balance algorithm for land (SEBAL) 1 Formulation. J Hydrol 1998; 212/213: 198-212. [doi:101016/S00221694(98)00253-4].

[68] Courault D, Seguin B, Olioso A. Review to estimate evapotranspiration from remote sensing data: some examples from the simplified relationship to the use of mesoscale atmospheric models, presented at 54th IEC Meeting of the International Commission on Irrigation and Drainage, 17 September 2003; Montpellier, France, Session 3.

[69] Gutschick VP. Plant acclimation to elevated CO2-From simple regularities to biogeographic chaos. Ecol Model 2007; 200(3-4): 43351. [doi:101016/jecolmodel200608013].

[70] Morse A, Tasumi M, Allen RG, Kramber W. Final report Application of the SEBAL methodology for estimating consumptive use of water and streamflow depletion in the Bear River Basin of Idaho through remote sensing. Idaho Department of Water Resources, University of Idaho, Moscow, Idaho 2000.

[71] van Leeuwen WJD, Orr B, Marsh SE, et al. The use of MODIS products in a geospatial decision support tool for rangeland monitoring. Proc of the 2004 10th Biennial Forest Svc Remote Sensing App Conf 2004.
[72] Ufnar DR, Frazier BE, Busacca AJ, Lammers D, Fisk H. Updating landtype association map techniques in region 6 using the TEUIgeospatial toolkit. Proc of the 2004 10th Biennial Forest Svc Remote Sensing App Conf 2004.

[73] van Leeuwen WJD, Sammons G. Seasonal land degradation risk assessment for Arizona. Proc of the 30th International Symposium on Remote Sens of Environ 2003.

[74] Gamon JA, Serrano L, Surfus JS. The photochemical reflectance index: An optical indicator of photosynthetic radiation use efficiency across species, functional types, and nutrient levels. Oecologia 1997; 112: 492501. [doi:101007/s004420050337].

[75] Guo JM, Trotter CM. Estimating photosynthetic light-use efficiency using the photochemical reflectance index: Variations among species Functional Plant Biology 2004; 31: 255-265. [doi:101071/FP03185].

[76] Drolet GG, Huemmrich KF, Hall FG, et al. A MODIS-derived photochemical reflectance index to detect inter-annual variations in the photosynthetic light-use efficiency of a boreal deciduous forest. Remote Sens Environ 2005; 98:212-224. [doi:101071/FP03185].

[77] Sims DA, Gamon JA. Estimation of vegetation water content and photosynthetic tissue area from spectral reflectance: a comparison of indices based on liquid water and chlorophyll absorption features. Remote Sens Environ 2003; 84: 526-37. [doi:101016/S00344257(02)00151-7].

[78] Dash J, Curran PJ. The MERIS terrestrial chlorophyll index. Int J Remote Sensing 2004; 25: 5403-54. [doi:101080/014311604200027 4015]

[79] Qi J, Chehbouni A, Huete AR, Kerr Y, Sorooshian S. A modified soil adjusted vegetation index (MSAVI). Remote Sens Environ 1994; 48: 119-26. [doi:101016/0034-4257(94)90134-1].

[80] Terrestrial biophysics and remote sensing lab. Enhanced vegitation index (EVI). Available from: http://tbrsarizonaedu/project/MODIS/ev iphp 2003.

[81] Wright R, Flynn L, Garbeil H, Harris A, Pilger E. Automated volcanic eruption detection using MODIS. Remote Sens Environ 2002; 82: 13555. [doi:101016/S0034-4257(02)00030-5].

[82] Rollins MG, Keane RE, Parsons RA. Mapping fuels and fire regimes using remote sensing, ecosystem simulation, and gradient modeling. Ecol Appl 2004; 14(1): 75-95. [doi:101890/02-5145].

[83] Sader S, Hoppus M, Metzler J, Jin S. Perspectives of maine forest cover change from Landsat imagery and forest inventory analysis (FIA). J Forestry 2005; pp. 299-303.

[84] Hernandez-Stefanoni JL, Ponce-Hernandez R. Mapping the spatial distribution of plant diversity indices in a tropical forest using multispectral satellite image classification and field measurements. Biodiversity Conserv 2004; 13: 2599-621. [doi:101007/s10531-0042137-2]

[85] Rude M. Communities at risk of wildfire on Alaska's Kenai Peninsula use remote sensing and mobile GIS tools on the ground. Proc of the 2004 10th Biennial Forest Svc Remote Sensing App Conf 2004.

[86] Puzzolo V, De Natale F, Giannetti F. Forest species discrimination in an alpine mountain area using a fuzzy classification of multi-temporal SPOT (HRV) data. Geoscience and Remote Sensing Symposium, 2003 IGARSS '03 Proceedings 2003 IEEE. Int 2003; 4: 2538-40.

[87] Ohmann JL, Matthew JG. Predictive mapping of forest composition and structure with direct gradient analysis and nearestneighbor imputation in coastal Oregon, USA. Can J For Res 2002; 32: 725-41. [doi: 101139/x02-011].

[88] Peña-barragán JM, López-granados F, Jurado-expósito M, García-torres L. Spectral discrimination of Ridolfia segetum and sunflower as affected by phenological stage. Weed Res 2006; 469(1) 10-21.

[89] Hyyppä J, Hyyppä H, Inkinen M, Engdahl M, Linko S, Y-H Zhu. Accuracy comparison of various remote sensing data sources in the retrieval of forest stand attributes. Forest Ecol Manag 2000; 128:10920. 